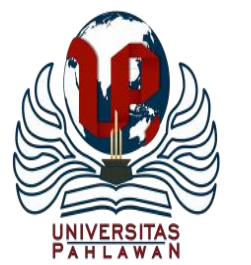

Edukatif : Jurnal Ilmu Pendidikan Volume 3 Nomor 4 Tahun 2021 Halm 2237 - 2244

EDUKATIF: JURNAL ILMU PENDIDIKAN

Research \& Learning in Education

https://edukatif.org/index.php/edukatif/index

\title{
Peningkatan Hasil Belajar IPS menggunakan Model Pembelajaran Make A Match pada Siswa Sekolah Dasar
}

\author{
M. Ihsan Ramadhani ${ }^{\bowtie}$ \\ Universitas Achmad Yani Banjarmasin, Indonesia \\ E-mail : ihsandikdas@uay.ac.id
}

\begin{abstract}
Abstrak
Penelitian ini bertujuan untuk mengetahui penggunaan model pembelajaran make a match dalam peningkatan Hasil Belajar IPS materi "Perjuangan Mempertahankan Kemerdekaan" siswa kelas V SDN Pantai Cabe Kabupaten Tapin. Metodologi penelitian menggunakan penelitian tindakan kelas yang dilaksanakan dengan dua siklus pada mata pelajaran IPS dengan subyek siswa kelas V. Jenis data yang digunakan dalam penelitian adalah kuantitatif dan kualitatif. Analisis data dilakukan dengan teknik persentase penilaian skala dan indikator keberhasilan ketuntasan. Hasil penelitian menunjukkan bahwa pelaksanaan aktivitas guru menggunakan model pembelajaran make a match siklus I mendapatkan presentase 77,94\% dengan kategori baik meningkat menjadi $86.74 \%$ dengan kategori sangat baik pada siklus II. Hasil belajar IPS materi "Perjuangan Mempertahankan Kemerdekaan" siswa kelas V pada siklus I memperoleh persentase $68,96 \%$ meningkat menjadi $86,20 \%$ di siklus II.
\end{abstract}

Kata Kunci: Model Pembelajaran, Make a Match, Hasil Belajar IPS.

\begin{abstract}
This study aims to determine the use of the make a match learning model in improving Social Studies Learning Outcomes for the fifth-grade students of SDN Pantai Cabe, Tapin Regency. The research methodology uses classroom action research which is carried out in two cycles on social studies subjects with class $V$ students as subjects. The types of data used in this research are quantitative and qualitative. Data analysis was carried out using the percentage of scale assessment techniques and indicators of completeness success. The results showed that the implementation of teacher activities using the make a match learning model in cycle I got a percentage of $77.94 \%$ with a good category increasing to $86.74 \%$ with a very good category in cycle II. The results of the social studies learning material "The Struggle to Maintain Independence" grade 5 students in the first cycle obtained a percentage of $68.96 \%$, increasing to $86.20 \%$ in the second cycle.
\end{abstract}

Keywords: Learning Model, Make a Match, Social Studies Learning Outcomes.

Copyright (c) 2021 M. Ihsan Ramadhani

$\triangle$ Corresponding author:

Email : ihsandikdas@uay.ac.id

DOI : https://doi.org/10.31004/edukatif.v3i4.1159

ISSN 2656-8063 (Media Cetak)

ISSN 2656-8071 (Media Online)

Edukatif : Jurnal Ilmu Pendidikan Vol 3 No 4 Tahun 2021 p-ISSN 2656-8063 e-ISSN 2656-8071 


\section{PENDAHULUAN}

Di zaman era globalisasi seperti dewasa ini, teknologi IPTEK berkembang semakin maju sehingga pendidikan juga dituntut semakin berkualitas. Pendidikan merupakan perbuatan manusiawi. Pendidikan lahir dari pergaulan antar orang dewasa dan orang yang belum dewasa dalam suatu kesatuan hidup. Mendidik yang dilakukan oleh pendidik dengan sengaja didasari oleh nilai-nilai kemanusiaan (Smk \& Yogyakarta, 2013)s. Tindakan tersebut menyebabkan orang yang belum dewasa menjadi dewasa dengan memiliki nilai-nilai kemanusiaan dan hidup menurut nilai-nilai tersebut. Kedewasaan diri merupakan tujuan pendidikan yang hendak dicapai melalui perbuatan atau tindakan pendidikan. Langeveld (dalam Hasbullah, 2012) mengemukakan pendidikan ialah setiap usaha, pengaruh, perlindungan dan bantuan yang diberikan kepada anak tertuju kepada pendewasaan anak atau lebih tepat membantu anak agar cakap untuk melakukan tugasnya sendiri (Astawa \& Tegeh, 2019).

Dalam kurikulum pada jenjang pendidikan dasar memuat sejumlah mata pelajaran salah satunya mata pelajaran IPS. IPS merupakan ilmu yang mempelajari tentang hubungan sosial antar individu dengan individu, individu dengan kelompok, kelompok dengan kelompok. Pengertian IPS menurut Djahiri dan Ma"mun (1978:2) adalah bahwa IPS merupakan konsep-konsep dari berbagai ilmu yang dijadikan satu dan diolah sesuai dengan tingkat perkembangan siswa (Yusuf Sukman, 2017). IPS sangat penting diajarkan karena bertujuan membentuk siswa menjadi warga negara yang memiliki ilmu pengetahuan, peduli terhadap lingkungan disekitarnya, cakap dan menjadi warga negara yang baik serta berguna bagi negaranya. Tujuan IPS akan tercapai setelah siswa melakukan kegiatan belajar. Jika belajar adalah prosesnya, maka hasil belajar adalah hasil perubahan dari kegiatan belajar yang dilakukan siswa (Wijendra, 2020). Dalam mengajarkan mata pelajaran IPS guru harus menguasai materi maupun keterampilan-keterampilan dalam mengajar, guru harus mampu memilih metode pembelajaran yang tepat dalam mengajarkan mata pelajaran IPS (Pujiwidodo, 2016). Guru atau calon guru harus mampu mengubah metode ceramah yang biasa mereka gunakan dengan metode-metode pembelajaran baru yang lebih kreatif dan inovatif sehingga mampu menumbuhkan partisipasi siswa dalam mengikuti pembelajaran di kelas maupun luar kelas sehingga hasil belajar mereka dapat meningkat (Aliputri, 2018). Hasil belajar sangatlah penting dalam kegiatan pembelajaran (Electric \& Technology, 2017). Jika dalam pembelajaran hasil belajar siswa rendah, maka dapat disimpulkan bahwa siswa tersebut tidak benar-benar belajar atau kegiatan pembelajaran yang dilakukan guru belum efektif. Sehingga tujuan pembelajaran IPS yang telah dirancang belum tercapai sepenuhnya. Melihat pentingnya hasil belajar siswa dalam kegiatan belajar, maka diharapkan semua siswa dapat mencapai hasil belajar yang tinggi (Kurniawan, 2017).

Namun berdasarkan observasi peneliti di SDN Pantai Cabe Kabupaten Tapin kelas V pada mata pelajaran IPS materi "Perjuangan Mempertahankan Kemerdekaan", dimana siswa cenderung kurang berpartisipasi aktif dalam proses pembelajaran, hanya 3 atau 4 siswa yang bertanya dan hanya 2 atau 3 dari siswa yang menjawab pertanyaan yang diajukan guru. Kenyataan ini diperkuat dari data nilai rata-rata hasil belajar IPS siswa kelas V materi "Perjuangan Mempertahankan Kemerdekaan" hanya mencapai 62,14 berada dibawah standar nilai Kriteria Ketuntasan Minimal (KKM) mata pelajaran IPS yang ditetapkan sekolah sebesar 70. Hal ini dapat di indikasikan bahwa pencapaian hasil belajar IPS siswa kelas V di SDN Pantai Cabe Kabupaten Tapin cenderung rendah disebabkan karena siswa merasa sulit dalam memahami materi, keaktifan siswa dalam mengikuti pembelajaran masih kurang, belum mengembangkan kemampuan berpikir kritis, rasional dan kreatif dalam menanggapi materi pelajaran IPS, sehingga tidak tertarik untuk belajar. Proses belajar mengajar sangat erat kaitannya dengan peran pendidik dalam kegiatan pembelajaran khususnya dalam peningkatan kualitas hasil dan proses pembelajaran. Ilmu Pengetahuan Sosial adalah program pendidikan yang mengintegrasikan secara interdisiplin konsep ilmu-ilmu sosial dan humaniora (Febriana, 2011). 
Permasalahan yang ada untuk mengatasinya, diperlukan suatu alternatif model pembelajaran yang tepat dan menarik. Salah satu model pembelajaran yang menarik menurut penulis untuk diterapkan adalah model pembelajaran kooeperatif tipe make a match. Menurut Rusman (2011) model pembelajaran kooeperatif tipe make a match salah satu jenis dari startegi dalam pembelajaran kooperatif. Strategi ini dikembangkan oleh Lorna Curan. Salah satu keunggulan strategi ini adalah siswa mencari pasangan sambil belajar mengenai konsep atau topik, dalam suasana yang menyenangkan. Selanjutnya ia mengatakan penerapan metode ini dimulai dengan teknik, yaitu siswa disuruh mencari pasangan kartu yang merupakan jawaban/soal sebelum batas waktunya, siswa yang dapat mencocokkan kartunya diberi poin. Menurut Melvin (2013) menyatakan strategi ini merupakan aktivitas kerjasama yang biasa digunakan untuk mengajarkan konsep, karakteristik klasifikasi, fakta tentang benda, atau menilai informasi. Gerak fisik yang ada di dalamnya dapat membantu menggairahkan siswa yang merasa penat. Dengan demikian model pembelajaran kooeperatif tipe make a match merupakan sebuah strategi pembelajaran yang membantu siswa untuk mendapat pengetahuan, keterampilan, dan sikap secara aktif serta menjadikan belajar tidak terlupakan pembelajaran yang membantu siswa untuk mendapat pengetahuan, keterampilan, dan sikap secara aktif serta menjadikan belajar tidak terlupakan (Pembelajaran, Tipe, Belajar, \& Samsur, 2018).

Proses pembelajaran yang baik bukan hanya terlihat dari siswa yang dapat memahami materi pembelajarannya saja, karena hal tersebut cenderung menekan dan memaksa siswa agar dapat memahami materi pelajarannya. Namun hal ini juga terkait dengan bagaimana seorang siswa dapat memahami materi dengan cara yang menyenangkan dan tidak menimbulkan perasaan tertekan dalam dirinya, sehingga dengan sendirinya proses belajar mengajar akan membuat siswa terlibat aktif (Saiselar, Palinussa, \& Tamalene, 2019). Proses pembelajaran khususnya pembelajaran IPS akan lebih efektif dan bermakna apabila siswa berpartisipasi aktif dimana ciri kebermaknaan dalam proses belajar mengajar adalah adanya keterlibatan atau partisipasi siswa dalam proses pembelajaran, dimana interaksi guru dan siswa pada saat proses belajar mengajar memegang peranan penting dalam mencapai tujuan atau kompetensi yang diinginkan khususnya dalam pembelajaran IPS di sekolah dasar (Dan, Siswa, \& Ii, n.d.). Pembelajaran IPS di sekolah dasar merupakan bidang studi yang mempelajari manusia dalam semua aspek kehidupan dan interaksinya dalam masyarakat, dimana peranan IPS sangat penting untuk mendidik siswa mengembangkan pengetahuan, sikap, dan keterampilan agar dapat mengambil bagian secara aktif dalam kehidupannya sebagai anggota masyarakat dan warga negara yang baik (Forests, 2015). Tujuan ini memberikan tanggung jawab yang berat kepada guru untuk menggunakan banyak pemikiran dan energi agar dapat mengajarkan IPS dengan baik. Munir (dalam Susanto, 2013) mengemukakan, pembelajaran IPS bertujuan untuk (1) membekali peserta didik tentang ilmu sosial yang berguna bagi kehidupan baik yang sekarang mapun pada masa yang akan datang (2) anak akan terbekali dengan kemampuan mengidentifikasi, menganalisis dan menyusun solusi pemecahan masalah yang berkaitan dengan kehidupan sosial (3) anak akan terlatih untuk berinteraksi (4) peserta didik akan mampu mengembangkan ilmu yang berkaitan dengan sosial (Putri \& Taufina, 2020).

Salah satu model pembelajaran yang dapat membantu siswa kelas V Pantai Cabe Kabupaten Tapin dalam meningkatkan hasil belajar IPS materi "Perjuangan Mempertahankan Kemerdekaan" mencapai prestasi adalah dengan menggunakan model pembelajaran make a match. Model pembelajaran make a match (membuat pasangan) merupakan salah satu jenis model dalam pembelajaran kooperatif (Walid, 2018). Model pembelajaran make a match dikembangkan oleh Lorna Curran. Model pembelajaran make a match (membuat pasangan) menekankan siswa untuk mencari pasangan sambil belajar mengenai suatu konsep atau topik dalam suasana yang menyenangkan (Laksmi, Jampel, \& Antara, 2017). Model pembelajaran make a match dapat membangkitkan aktivitas siswa, meningkatkan motivasi siswa, membantu proses perkembangan anak, serta juga dapat membantu anak untuk bisa bekerjasama dengan temannya dalam menjawab pertanyaan dengan mencocokkan kartu yang ada ditangan siswa (Mulyani, Studi, Matematika, \& Purworejo, 2014). Dengan menggunakan model pembelajaran Make A Match membuat siswa akan aktif dan memiliki pengalaman 
belajar yang bermakna, sehingga model Make A Match dapat dijadikan alternatif untuk meningkatkan hasil belajar siswa (Saiselar et al., 2019). Tujuan dari model pembelajaran make a match adalah untuk membina keterampilan, dan menemukan informasi, menumbuhkan semangat kerjasama dengan orang lain, serta membina tanggung jawab untuk memecahkan soal atau masalah yang dihadapi melalui kartu persoalan atau permasalahan. Model kooperatif make a match dapat meningkatkan aktivitas belajar siswa, meningkatkan pemahaman siswa terhadap materi, meningkatkan motivasi belajar siswa, melatih keberanian siswa untuk tampil presentasi, melatih kedisplinan siswa dan di dalam model kooperatif make a match ini terdapat unsur permainan yang membuat siswa merasa senang sehingga dapat meningkatkan hasil belajar siswa (Kurniawan, 2017).

Beberapa hasil penelitian terdahulu tentang penerapan model pembelajaran kooperatif tipe Make A Match dalam kegiatan pembelajaran antara lain adalah penelitian yang yang telah dilakukan oleh Riyanto (2009) yang di muat dalam jurnal penelitian dengan judul Peningkatan Motivasi Belajar dan Hasil Belajar PKN Melalui Model Pembelajaran "Make A Match" Pada siswa kelas VIIC SMP Negeri 1 Ngawen Kabupaten Blora Tahun 2008/2009 (Laksmi et al., 2017). Pada siklus 1 motivasi siswa dalam menerima pelajaran diklasifikasikan sebagai berikut: $34 \%$ siswa menunjukkan motivasi tinggi yang ditandai dengan ketepatan mencari pasangan, adanya kerjasama yang baik dalam mengerjakan tugas, keberanian dalam mempresentasikan hasil, berargumentasi maupun bertanya, sedangkan siswa yang mempunyai motivasi sedang sebanyak $42,7 \%$, dan 23,3\% motivasi siswa rendah. Pada siklus 2 siswa yang mempunyai motivasi tinggi sebanyak 40\%, 44\% motivasi siswa sedang, dan $16 \%$ motivasi siswa rendah. Peningkatan hasil belajar siswa pada pembelajaran PKN dari 55 menjadi 77. Dari data di atas menunjukkan bahwa adanya peningkatan motivasi dan hasil belajar siswa dalam menerima pembelajaran dengan menggunakan model pembelajaran kooperatif tipe Make A Match. (http://jurnal.pdii.lipi.go.id/admin/jurnal/22095663.pdf) diakses pada hari selasa 4 Agustus 2021 pukul 07.45 WIB.

Berdasarkan uraian di atas, maka peneliti tertarik untuk melakukan penelitian dengan judul Peningkatan Hasil Belajar IPS Menggunakan Model Pembelajaran Make A Match Pada Siswa Sekolah Dasar. Pentingnya penelitian ini dilakukan yaitu untuk mengetahui penggunaan model pembelajaran make a match dalam peningkatan hasil belajar IPS materi "Perjuangan Mempertahankan Kemerdekaan" siswa kelas V SDN Pantai Cabe Kabupaten Tapin. Penelitian ini nantinya diharapkan dapat melatih siswa lebih cermat, dapat berpikir cepat, ulet, dan memiliki pemahaman yang kuat mengenai materi serta dapat berinteraksi sosial dengan temannya.

\section{METODOLOGI}

Pendekatan dalam penelitian ini adalah pendekatan kualitatif dan kuantitatif dengan jenis Penelitian Tindakan Kelas (Classroom Action Research) yang bertujuan untuk memberikan pengetahuan dan inovasi pembelajaran menggunakan model pembelajaran make a match dalam meningkatkan hasil belajar IPS materi "Perjuangan Mempertahankan Kemerdekaan" siswa kelas V SDN Pantai Cabe Kabupaten Tapin (Nuladani, Kurniasih, Studi, Matematika, \& Purworejo, n.d.). Penelitian tindakan kelas diartikan sebagai proses pengkajian masalah pembelajaran didalam kelas melalui refleksi diri dalam upaya untuk memecahkan masalah tersebut dengan cara melakukan berbagai tindakan yang terencana dalam situasi nyata serta menganalisis setiap pengaruh dari perlakuan tersebut (Nuladani et al., n.d.). Dinyatakan ada empat tahapan yang sering digunakan dalam penelitian tindakan kelas, sebagai berikut (Kurniawan, 2020):

1. Perencanaan, yaitu mengembangkan rencana tindakan yang secara kritis berdasar permasalahan untuk meningkatkan apa yang telah terjadi, misalnya membuat rencana pelaksanaan pembelajaran (RPP), membuat Lembar Kerja Siswa (LKS), dan menyusun alat evaluasi sesuai indikator hasil belajar (Astawa $\&$ Tegeh, 2019). 
2241 Peningkatan Hasil Belajar IPS menggunakan Model Pembelajaran Make A Match pada Siswa Sekolah Dasar-M. Ihsan Ramadhani

DOI: https://doi.org/10.31004/edukatif.v3i4.1159

2. Pelaksanaan Tindakan, yaitu tindakan yang dilakukan secara sadar dan terkendali, yang merupakan variasi praktik yang cermat dan bijaksana untuk memperbaiki keadaan yang akan dilakukan.

3. Observasi, yaitu mendokumentasikan atau pengumpulan data yang berupa proses perubahan kinerja Proses Belajar Mengajar (PBM) observasi perlu direncanakan dan juga didasarkan dengan keterbukaan pandangan pikiran.

4. Refleksi, yaitu mengingat dan merenungkan suatu tindakan persis seperti yang dicatat dalam observasi. Refleksi (perenungan) merupakan kegiatan analisis, interpretasi (penjelasan) terhadap semua informasi yang diperoleh dari observasi atau pelaksanaan tindakan.

Penelitian dilaksanakan pada mata pelajaran IPS siswa kelas V SDN Pantai Cabe Kabupaten Tapin semester II tahun ajaran 2020/2021 dengan jumlah siswa 29 orang. Data dianalisis menggunakan data kualitatif dan kuantitatif, dengan rincian : (a) data kualitatif berupa data tentang aktivitas guru menerapkan model pembelajaran make a match dalam meningkatkan Hasil Belajar IPS materi "Perjuangan Mempertahankan Kemerdekaan", (b) data kuantitatif berupa nilai Hasil Belajar IPS siswa materi "Perjuangan Mempertahankan Kemerdekaan". Adapun indikator keberhasilan dalam penelitian ini, yaitu : (1) Aktivitas Guru, dikategorikan berhasil apabila $\geq 80 \%$ dengan kategori sangat baik, dan (2) Aktivitas siswa, dikategorikan berhasil apabila $\geq 80 \%$ siswa tuntas dari kriteria ketuntasan hasil belajar IPS materi "Perjuangan Mempertahankan Kemerdekaan” siswa kelas V SDN Pantai Cabe Kabupaten Tapin.

\section{HASIL DAN PEMBAHASAN}

\section{Aktivitas Guru}

Berdasarkan hasil analisis data penelitian, aktivitas guru dalam menggunakan model pembelajaran make a match siklus I dan siklus II pada tabel observasi berikut ini :

\section{Tabel 1}

Rekapitulasi Aktivitas Guru Siklus I dan Siklus II

\begin{tabular}{ccc}
\hline & Aktivitas Guru & \\
\hline Siklus & Persentase & Kualifikasi \\
\hline I & 77,94 & Baik \\
\hline II & 86,76 & Sangat Baik \\
\hline
\end{tabular}

Tabel 1 menunjukkan bahwa aktivitas guru dalam proses pembelajaran IPS mengalami peningkatan, terlihat dari siklus I persentase yang diperoleh 77,94 dengan kualifikasi baik dan siklus II persentase yang diperoleh mencapai 86,76 dengan kualifikasi sangat baik. Hal ini menyatakan bahwa kualitas guru dalam menerapkan model pembelajaran make a match sangat baik seperti aspek memberikan motivasi, melakukan berbagai variasi strategi dan ice breaking, membimbing siswa dalam menyelesaikan permainan (mencocokkan kartu soal/kartu jawaban), memberikan pujian dan reward siswa yang berhasil menyelesaikan permainan (mencocokkan kartu soal/kartu jawaban) tepat dan sesuai waktu yang telah disepakati guru dan siswa serta menyimpulkan materi pembelajaran. Dinyatakan pembelajaran yang menyenangkan bagi setiap orang yang berada di dalam kelas atau sekolah dan kegiatannya berpusat pada siswa (Heldaenni, 2018). Berdasarkan hasil siklus I dan siklus II, aktivitas guru menggunakan model pembelajaran make a match sudah dianggap berhasil dan mampu meningkatkan aktivitas guru dalam pembelajaran IPS.

\section{Hasil Belajar IPS}

Berdasarkan hasil belajar IPS materi "Perjuangan Mempertahankan Kemerdekaan" siswa kelas V SDN Pantai Cabe Kabupaten Tapin setelah menerapkan model pembelajaran make a match siklus I dan siklus II pada tabel berikut ini: 
2242 Peningkatan Hasil Belajar IPS menggunakan Model Pembelajaran Make A Match pada Siswa Sekolah Dasar-M. Ihsan Ramadhani

DOI: https://doi.org/10.31004/edukatif.v3i4.1159

Tabel 2

Rekapitulasi Ketuntasan Hasil Belajar IPS Siswa Kelas V Siklus I dan Siklus II

\begin{tabular}{ccccc}
\hline & \multicolumn{2}{c}{ Siklus I } & \multicolumn{2}{c}{ Siklus II } \\
\cline { 2 - 5 } & \multicolumn{2}{c}{ Pertemuan 1 } & \multicolumn{2}{c}{ Pertemuan 1 } \\
\hline \multirow{2}{*}{ Ketuntasan } & Siswa Yang Tuntas & Presentase & Siswa Yang Tuntas & Presentase \\
\cline { 2 - 5 } & 20 & $68.96 \%$ & 25 & $86.20 \%$ \\
\hline
\end{tabular}

Berdasarkan tabel 2 siklus I pertemuan pertama pada hasil belajar IPS siswa kelas V SDN Pantai Cabe Kabupaten Tapin persentase ketuntasan mencapai $68.96 \%$, dimana siswa masih belum mendapat kentuntasan hasil belajar IPS siswa kelas V SDN Pantai Cabe Kabupaten Tapin yang diharapkan, siswa cenderung belum terbiasa menerapkan langkah-langkah model pembelajaran make a match dalam pembelajaran IPS, sehingga hasil belajar IPS siswa kelas V SDN Pantai Cabe Kabupaten Tapin belum maksimal. Guru merefleksikan permasalahan di siklus I dengan mengkombinasikan ice breaking dan model pembelajaran make a macth serta memotivasi siswa dalam proses pembelajaran IPS. Selanjutnnya hasil belajar IPS materi "Perjuangan Mempertahankan Kemerdekaan" siswa kelas V SDN Pantai Cabe Kabupaten Tapin di siklus II pertemuan pertama persentase ketuntasan yang dicapai meningkat menjadi 86.20\%. Suyono dan Hariyanto, (2011:127) mendeskripsikan bahwa hasil belajar dikatakan meningkat apabila ditandai oleh dengan perubahan tingkah laku siswa secara keseluruhan, ketika pembelajaran berlangsung dan dalam berkelompok dengan berbagai strategi maupun media pembelajaran yang diterapkan. Model pembelajaran make a match dapat digunakan untuk membangkitkan aktivitas siswa belajar dan cocok digunakan dalam bentuk permainan (Mulyatiningsih, 2012:248) (Jacobsen, 2008). Berdasarkan hasil belajar IPS siklus I dan II dengan penerapan model pembelajaran make a match dapat meningkatkan hasil belajar IPS materi "Perjuangan Mempertahankan Kemerdekaan" siswa kelas V SDN Pantai Cabe Kabupaten Tapin.

Penggunaan model Make A Match dalam pembelajaran IPS melibatkan siswa untuk belajar mengenai suatu konsep dalam suasana yang menyenangkan . Keunggulan model Make A Match adalah siswa mencari pasangan menggunakan kartu soal dan jawaban sambil belajar mengenai suatu konsep atau topik dalam suasana yang menyenangkan. Sehingga siswa lebih mudah memahami materi yang diberikan. Hal ini diperkuat dengan hasil penelitian Riyanto (2009) yang di muat dalam jurnal penelitian dengan judul Peningkatan Motivasi Belajar dan Hasil Belajar PKN Melalui Model Pembelajaran "Make A Match" Pada siswa kelas VIIC SMP Negeri 1 Ngawen Kabupaten Blora Tahun 2008/2009 (Mulyani et al., 2014). Pada siklus 1 motivasi siswa dalam menerima pelajaran diklasifikasikan sebagai berikut: 34\% siswa menunjukkan motivasi tinggi yang ditandai dengan ketepatan mencari pasangan, adanya kerjasama yang baik dalam mengerjakan tugas, keberanian dalam mempresentasikan hasil, berargumentasi maupun bertanya, sedangkan siswa yang mempunyai motivasi sedang sebanyak 42,7\%, dan 23,3\% motivasi siswa rendah. Pada siklus 2 siswa yang mempunyai motivasi tinggi sebanyak 40\%, 44\% motivasi siswa sedang, dan $16 \%$ motivasi siswa rendah. Peningkatan hasil belajar siswa pada pembelajaran PKN dari 55 menjadi 77. Dari data di atas menunjukkan bahwa adanya peningkatan motivasi dan hasil belajar siswa dalam menerima pembelajaran dengan menggunakan model pembelajaran kooperatif tipe Make A Match. Oleh karena itu adanya kesesuaian antara penelitian yang dilakukan peneliti dan penelitian terdahulunya bahwa model Make A Match sangat cocok diterapkan dalam pembelajaran IPS di sekolah dasar, karena siswa dapat menemukan pengetahuan secara langsung melalui kegiatan-kegiatan yang ada dalam model Make A Match dengan bimbingan guru.

\section{KESIMPULAN}

Berdasarkan hasil penelitian menggunakan model pembelajaran make a match siswa kelas V SDN Pantai Cabe Kabupaten Tapin, dapat disimpulkan bahwa adanya peningkatan hasil belajar yang ditandai dengan perubahan tingkah laku siswa secara keseluruhan, ketika pembelajaran berlangsung dan dalam berkelompok dengan berbagai strategi maupun media pembelajaran yang diterapkan. Model pembelajaran 
2243 Peningkatan Hasil Belajar IPS menggunakan Model Pembelajaran Make A Match pada Siswa Sekolah Dasar-M. Ihsan Ramadhani

DOI: https://doi.org/10.31004/edukatif.v3i4.1159

make a match dapat digunakan untuk membangkitkan aktivitas siswa belajar dan cocok digunakan dalam bentuk permainan. Berdasarkan penelitian telah terbukti bahwa adanya peningkatan motivasi dan hasil belajar siswa dalam menerima pembelajaran dengan menggunakan model pembelajaran kooperatif tipe Make A Match. Sehingga model Make A Match sangat cocok diterapkan dalam pembelajaran IPS di SD, karena siswa dapat menemukan pengetahuan secara langsung melalui kegiatan-kegiatan yang ada dalam model Make $A$ Match dengan bimbingan guru. Selain itu juga peneliti ingin memberikan saran kepada Guru agar dapat menerapkan model Make A Match dalam mata pelajaran IPS, disamping itu guru diharapkan dapat mengoptimalkan pembelajaran dengan memilih serta menggunakan model pembelajaran yang tepat, melakukan refleksi terhadap pembelajaran yang dilakukan dan tindakan perbaikan sehingga dapat mencapai tujuan pembelajaran yang ingin dicapai.

\section{DAFTAR PUSTAKA}

Aliputri, D. H. (2018). Penerapan Model Pembelajaran Kooperatif Tipe Make A Match Berbantuan Kartu Bergambar Untuk Meningkatkan Hasil Belajar Siswa. Jurnal Bidang Pendidikan Dasar, 2(1 A), 70-77. https://doi.org/10.21067/jbpd.v2i1a.2351

Astawa, P. A., \& Tegeh, I. M. (2019). Pengaruh Model Pembelajaran Kooperatif Tipe Make A Match Berbantuan Media Powerpoint Terhadap Hasil Belajar IPA. Jurnal Ilmiah Sekolah Dasar, 3(1), 98. https://doi.org/10.23887/jisd.v3i1.17663

Dan, P., Siswa, P., \& Ii, K. (n.d.). 1, 2 , 3. 1-6.

Electric, S., \& Technology, P. (2017). R1. 2. 3. . 3-10.

Febriana, A. (2011). ( Application of Cooperative Learning Model Type Make A Ayu Febriana Teacher at Primary School Kalibantengkidul 1, Semarang Abstract. Jurnal Kependidikan Dasar, 2, 151-161. Retrieved from https://media.neliti.com/media/publications/120456-ID-determinasi-pemanfaatanlingkungan-sekit.pdf

Forests, R. (2015). 高橋 由佳 †1) 藤本 悠 †2) 林 泰弘 †3) †. Cybrarians Journal, 2(37), 1-31.

Heldaenni, H. (2018). Penerapan Model Pembelajaran Kooperatif Tipe Make a Match Untuk Meningkatkan Hasil Belajar Ips Siswa Kelas Ii Sd Negeri 025 Teluk Binjai Dumai Timur. JURNAL PAJAR (Pendidikan Dan Pengajaran), 2(3), 405. https://doi.org/10.33578/pjr.v2i3.5537

Jacobsen, E. K. (2008). Make a Match. Journal of Chemical Education, 85(8), 1090. https://doi.org/10.1021/ed085p1090

Kurniawan. (2017). No Title日本の国立公園に関する 3 拙著に対する土屋俊幸教授の批評に答える 経済志林, 87(1,2), 149-200.

Kurniawan, G. E. (2020). Pengaruh Model Pembelajaran Kooperatif Tipe Mencari Pasangan (Make A Match) Terhadap Hasil Belajar Siswa Pembelajaran IPA Pokok Bahasan Benda dan .... Jurnal Pendidikan Fisika Dan Sains ..., 3(1), 29-34. Retrieved from http://journal.unucirebon.ac.id/index.php/jpfs/article/view/79

Laksmi, N. M. S., Jampel, I. N., \& Antara, P. A. (2017). Pengaruh Model Pembelajaran Make A Match terhadap Kemampuan Konsep Bilangan pada Anak Kelompok B. E-Journal Pendidikan Anak Usia Dini Universitas Pendidikan Ganesha Jurusan Pendidikan Guru Pendidikan Anak Usia Dini, 5(1), 1-12.

Mulyani, A., Studi, P., Matematika, P., \& Purworejo, U. M. (2014). Menggunakan Model Pembelajaran Kooperatif Tipe Make A. 29-34.

Nuladani, F., Kurniasih, N., Studi, P., Matematika, P., \& Purworejo, U. M. (n.d.). Pengaruh Pembelajaran Matematika dengan Model Classroom Meeting Dikombinasikan Make A Match terhadap Kemandirian dan Prestasi Belajar Siswa. 195-200. 
2244 Peningkatan Hasil Belajar IPS menggunakan Model Pembelajaran Make A Match pada Siswa Sekolah Dasar-M. Ihsan Ramadhani

DOI: https://doi.org/10.31004/edukatif.v3i4.1159

Pembelajaran, M., Tipe, K., Belajar, H., \& Samsur, I. P. S. (2018). Penerapan Model Pembelajaran Kooeperatif Tipe Make A Match untuk Meningkatkan Hasil Belajar IPS Siswa Kelas V Sekolah Dasar Samsur samsurmursinah @ gmail .com SD Negeri 54 Sebangar Kecamatan Mandau Kabupaten Bengkalis PENDAHULUAN Pendidikan IPS sekolah m. 7(April), 170-177.

Pujiwidodo, D. (2016). No

主観的健康感を中心とした在宅高齢者における＼cjkstart健康関連指標に関する共分散構造分析Title. III(2), 2016.

Putri, E. N. D., \& Taufina, T. (2020). Pengaruh Model Kooperatif Tipe Make A Match Terhadap Hasil Belajar Siswa di Sekolah Dasar. Jurnal Basicedu, 4(3), 617-623. https://doi.org/10.31004/basicedu.v4i3.405

Saiselar, B. G., Palinussa, A., \& Tamalene, H. (2019). Komparasi Hasil Belajar Siswa Menggunakan Model Pembelajaran Kooperatif Tipe Tai Dan Model Pembelajaran Konvensional Pada Materi Integral. Science Map Journal, 1(1), 29-36. https://doi.org/10.30598/jmsvol1issue1pp29-36

Smk, D. I., \& Yogyakarta, N. (2013). Penerapan Metode Pembelajaran Make A Match untuk Meningkatkan Hasil Belajar Siswa Kelas X Jasa Boga pada Mata Diklat Pelayanan Makan dan Minum The Application of the Make A Match Learning Model to Improve the Learning Outcomes of Grade X Students of Culin. (2).

Walid, M. (2018). $\square \square \square \square \square \square \square \square \square \square \square \square \square \square \square \square \square \square \square \square \square \square \square \square \square \square \square \square$ 11(1).

Wijendra, I. W. (2020). Penggunaan Model Pembelajaran Make A Match Sebagai Upaya Meningkatkan Prestasi Belajar Bahasa Indonesia. Mimbar Pendidikan Indonesia, 1(2), 240-246. https://doi.org/10.23887/mpi.v1i2.30199

Yusuf Sukman, J. (2017). Опыт аудита обеспечения качества и безопасности медицинской деятельности в медицинской организации по разделу «Эпидемиологическая безопасностьNo Title. Becтник Росздравнадзора, 4(02), 9-15. 